monohrafiia. [Theoretical and methodological foundations of learning differentiation]. Lviv.

\section{ВІДОМОСТІ ПРО АВТОРА}

ІСТИНЮК Ірина Дмитрівна - доцент кафедри педагогіки та методики початкової освіти Чернівецького національного університету імені Юрія Федьковича.

Наукові інтереси: підготовка до школи, інноваційні технології виховання, трудове навчання та виховання школярів та студентів.
INFORMATION ABOUT THE AUTHOR

ISTYNIUK Iryna Dmytrivna - Associate Professor of Pedagogy and Methods of Primary Education, Yuri Fedkovych Chernivtsi National University.

Circle of scientific interests: school preparation, innovative technologies of education, labor training and education of schoolchildren and students.

Стаття надійшла до редакиії 27.01.2020 p.

УДК $811.111(072): 004.032 .6$

DOI: 10.36550/2415-7988-2020-1-188-89-91

KAPITAN Tatiana Anatoliivna -

Candidate of Philological Sciences, Associate Professor of the Department of Linguodidactics and Foreign Languages of Volodymyr Vynnychenko Central Ukrainian State Pedagogical University ORCID:https://orcid.org/0000-0002-9999-9293 e-mail: Kapitan_18@mail.ua

\title{
USING MULTIMEDIA TECHNOLOGIES IN FOREIGN LANGUAGE LESSONS
}

Formulation and justification of the relevance of the problem. At the present stage, the education system faces the problem of training educators who have a high level of readiness to solve pedagogical and methodological tasks with the help of multimedia technologies. Multimedia technologies are one of the promising directions of the use of information and computer technologies in the field of humanitarian education. As we know, multimedia technologies contribute to the widespread use of interactive methods.

In our opinion, the problem of using multimedia presentations in foreign language lessons is that there are no advanced, professionally designed multimedia educational materials. These issues are very topical and require detailed study.

Analysis of recent research and publications. The problem of studying and using multimedia technologies in foreign language lessons is the subject of research of both foreign and national scientists, among them: T. Solovyov, B. Kruse, A. Kostenko, V. Korzh, B. Andersen et al.

The purpose of the article is investigation of the problem of using multimedia technologies in foreign language classes.

The main material of the study. Modern foreign language teachers in order to interest students in their subject, must use the latest methods and teaching tools and only multimedia technologies can increase its effectiveness.
The use of multimedia technology optimizes the learning process, makes it interesting and interactive, and enables the realization of multimedia competence of foreign language teachers. Skills and ability to create multimedia training materials are important components of this competence [2, p. 51].

Hyperlinks and presentations are the main multimedia product for younger students when learning a foreign language. Mastering the methodology of creating hyperlinks and multimedia presentations depends on the formation of major components of multimedia competence of future foreign language teachers, in particular [2, p. 91-94].

A hyperlink is a link from one electronic information object to another (for example, a text on a note or a list item). A special program (browser) recognizes bookmarks in the text and navigates to a particular piece of text or to another file [6, p. 75].

Another example of multimedia technology is a multimedia computer presentation, a document that is used to provide concise visual information. Computer and projection technology is used to demonstrate computer presentations: computers, multimedia projectors, monitors, multimedia and interactive whiteboards that provide computer feedback, and more. There are two main types of presentations: streaming (a set of frames that play automatically, changing each other at welldefined intervals); Slide (designed and demonstrated as a slide sequence that separates on-screen pages that may contain text, graphics, 
videos, sound objects, and hyperlinks that can be played as directed by the user). Slideshows are like photos, streaming presentations or a movie. To create computer presentations use: presentation graphics tools (special programs designed to create images and display them on the screen, prepare slideshows, cartoons, edit them); slide presentation tools (Microsoft Office PowerPoint, OpenOffice. org Impress, Powerbuller Presenter, ProShow Producer, Quick Slide Show, MySlideShow); tools for creating streaming presentations (Adobe Flash, Microsoft Movie Maker, Macromedia Flash, AnFX Visual Design, Virtual Tour Builder) [7].

According to A. Kostenko, tools for creating streaming presentations have more powerful capabilities: creating animated images, cartoons, videos and more. The main advantage of slide presentations is the ease of creating and managing their playback, while customizing the display of streaming presentations requires the creation of special buttons, stills, programming basics, etc. [2, p. 54].

Using multimedia presentations is a way of engaging students in educational activities. In our opinion, it enables the teacher to show their creativity. Using presentations allows you to achieve the optimum pace of students'work, to increase the level of visibility in the course of learning, to study more material, to increase cognitive interest, to revive the learning process, to achieve the effect of rapid feedback. Today, multimedia presentations have become an active part of the modern learning process. One of the possibilities of using multimedia technologies in lessons is the preparation and conduct of integrated lessons. Using multimedia technologies in a foreign language lesson is one of the most important aspects of improving the initial process, extensions of teaching tools and technigues that make a lesson interesting.

According to L. Lysenko, thanks to multimedia you can provide a wealth of useful, interesting and important information when studying the course «English for Professional Purpose». The undeniable advantage of multimedia is interactivity that provides dialog mode throughout learning process. The basic principles of using multimedia tools in the course include: decoration of the illustrations; fragmentation (alternate teaching of parts of material depending on the speed of perception by students); methodical invariance (video materials are used at different stages of the course), performing test tasks (using a computer), consolidating and generalizing knowledge (manual for independent work), homework (media presentation), individual research work (students work independently or groups on the creation of media presentations on the culture of professional broadcasting, terminological and professional ethics, etc.) [4, p. 126].

Foreign language learning has cognitive and developmental character and, as a result, it stimulates students' speech and mental activity, so it is necessary to apply such technologies to language learning that would facilitate intellectual and communicative development of the subjects' of cognition. Such technologies include, first of all, multimedia technologies [1, p. 14].

One of the innovative pedagogical computer technologies can be called multimedia technologies - a set of methods, tools and techniques for collecting, accumulating, processing, storing, transmitting, producing, structuring and integrating audiovisual, text and graphic information in terms of interactive interaction of the user with information system, realizes possibilities of multimedia operating environments [1, p. 33].

Multimedia technologies provide simultaneous operation of several channels of perception of information (but also involve involvement of both hemispheres of the brain). Students have great opportunities in creative use of information resources, oriented both on space (text, graphics), and on time (sound, animation, video) [5].

For effective use of a multimedia product (multimedia) in the educational process, teachers need to have multimedia competence, which includes, according to B. Cruz, cumulative readiness, ability and experience of applying multimedia competencies (relevant knowledge, skills and abilities) [3, p. 84].

Conclusions and prospects for further research of the direction. The use of multimedia technology optimizes the learning process, makes it interesting and interactive, and also enables the implementation of multimedia competence of foreign language teachers. In this way, multimedia can provide a wealth of useful, interesting and important information during the learning process, insofar multimedia meets the basic principles of modern learning - visibility, consciousness, activity, individualization, intensification, communicativeness.

Thus, the use of multimedia technologies is one of the promising directions of increasing cognitive activity of students. The unlimited possibilities of the computer to provide information solve the problem of constant changes and updating of the content of school education.

Using multimedia, we achieve the primary 
goal of learning - to nurture a person who is able to develop in today's society.

\section{СПИСОК ДЖЕРЕЛ}

1. Вовк О. І., Костенко А. А. Методика навчання англомовного спілкування учнів початкової школи. Курс лекцій / О. І. Вовк, А. А. Костенко. Ч.: Видавець: Нечитайло О. Ф., 2014. $127 \mathrm{c}$.

2. Костенко А. А. Застосування мультимедійних технологій у навчанні іноземної мови учнів початкової школи / А. А. Костенко. Черкаси: Видавець Чабаненко Ю. А., 2014. 158 с.

3. Крузе Б. А. Мультимедийная компетентность учителя / Б. А. Крузе // Педагогическое образование и наука. 2009. № 6. С. 82-84.

4. Лисенко Л. О. Використання IT-технологій при вивченні англійської мови за професійним спрямуванням / Л. О. Лисенко // Наукові записки ЦДПУ ім. В. Винниченка. Серія: Педагогічні науки. Випуск 178. Кропивницький, 2019. С. 125 128.

5. Роль медиа в современном мире и образовании. Лекционный курс (тезисы), [Електронный ресурс]. URL: $\mathrm{http} / / /$ mediapedagogics.ru/lectures.html

6. Теоретические основы создания образовательных электронных изданий / М. И. Беляев, В. М. Вымятнин, С. Г. Григорьев и др. Томск, 2002

7. Цвилева Я. Засоби презентаційної графіки. [Електронний ресурс] / Я. Цвилева. URL: http://informat.in.ua/zasob\% D1\%97grafiki.html.

\section{REFERENCES}

1. Vovk, O. I., Kostenko, A. A. (2014). Metodyka navchannia anhlomovnoho spilkuvannia uchniv pochatkovoi shkoly. Kurs lektsii. [Methods of teaching English language communication to elementary school students].

2. Kostenko, A. A. (2014). Zastosuvannia multymediinykh tekhnolohii u navchanni inozemnoi movy uchniv pochatkovoi shkoly. [Application of Multimedia Technologies in Elementary School Students' Foreign Language Teaching]. Cherkasy.

3. Kruze, B. A. (2009). Multymedyinaia kompetentnost uchytelia. [Multimedia Teacher Competence].

4. Lysenko, L. O. Vykorystannia. (2019). ITtekhnolohii pry vyvchenni anhliiskoi movy za profesiinym spriamuvanniam. [The use of IT technologies in the study of English language by professional direction]. Kropyvnytskyi.

5. Rol media $v$ sovremennom mire y obrazovanii. Lektsyonnyi kurs (tezisy). [The role of media in today's world and education.]

6. Teoreticheskie osnovy sozdaniya obrazovatelnykh elektronnykh izdaniy. (2002). [Theoretical Foundations of Creating Educational Electronic Publications]. Tomsk.

7. Tsvyleva, Ya. Zasoby prezentatsiinoi hrafiky. [Tools of presentation graphics]

\section{ВІДОМОСТІ ПРО АВТОРА}

КАПІТАН Тетяна Анатоліївна - кандидат філологічних наук, доцент кафедри лінгводидактики та іноземних мов Центральноукраїнського державного педагогічного університету імені Володимира Винниченка.

Наукові інтереси: методика викладання іноземних мов у школі.

INFORMATION ABOUT THE AUTHOR

KAPITAN Tetiana Anatoliivna - Candidate of Philological Sciences, Associate Professor, Department of Linguodidactics and Foreign Languages of Volodymyr Vynnychenko Central Ukrainian State Pedagogical University.

Circle of scientific interests: methodology of foreign language teaching in school.

Стаття надійшла до редакиї 22.01.2020 p.

КОЖЕВНІКОВА Лариса Василівна кандидат педагогічних наук, доцент кафедри мистецьких дисциплін і методик навчання ДВНЗ «Переяслав-Хмельницький державний педагогічний університет імені Григорія Сковороди» ORCID:https://orcid.org/0000-0002-8535-8727 e-mail:L0681813681@gmail.com

\section{ФОРМУВАННЯ КОМУНІКАТИВНОӤ КОМПЕТЕНТНОСТІ МАЙБУТНЬОГО ВЧИТЕЛЯ} МУЗИЧНОГО МИСТЕЦТВА

\author{
Постановка та обтрунтування \\ актуальності проблеми. Необхідність \\ виховання нової генерації педагогічних \\ кадрів і розробка комплексу теоретичних та
}

методичних основ забезпечення педагогічного процесу $\epsilon$ одним із актуальних питань сьогодення. Музичне мистецтво як свосрідна форма пізнання дійсності 